\title{
THE ASSESSMENT OF THE STRUCTURAL CHANGES OF FINE- GRAINED CEMENT-BASED COMPOSITES IN THE EARLY-AGE USING ACOUSTIC TESTING
}

\author{
MICHAELA HODULÁKOVÁ*, LIBOR TOPOLÁR̆ \\ Brno University of Technology, Veveř́ 331/95, 60200 Brno, Czech Republic \\ *E-mail: hodulakova.m@fce.vutbr.cz
}

\begin{abstract}
The paper deals with the monitoring of the structural changes of fine-grained cement-based composites in the early-age using acoustic emission method. After mixing, the cement-based materials exhibit continuous time-dependent structural changes which lead to the changes in the mechanical properties due to the chemical and physical processes. The events which are emitted due to the internal structure formation were detected using the acoustic emission techniques. A number of AE events are released due to the formation of new crystalline phases and due to microcracking in the material structure during the setting and hardening. The aim of the performed experiments was to extend the knowledge in the field of the early-age material characteristics and in the field of the internal structure formation of the cement-based materials. The results from temperature measurement show that mixture with microsilica has more slowly raised the internal temperature than mixture without microsilica. The results from acoustic emission measurement show that mixture with microsilica has lower activity of acoustic emission than mixture without microsilica during first six hours from measurement start.
\end{abstract}

Keywords: acoustic emission method, non-destructive testing, microcracks, fine-grained cement-based composites

\section{Introduction}

Acoustic emission (AE) method is a quite unique non-invasive and passive non-destructive technique which identifies defects only while these defects develop during the monitoring. The evaluation of acoustic emission events may be continuous (during the experiment) or can be made subsequently after the experiment $[1,2]$.

Every fracture in a specimen takes place with the release of stored strain energy. This energy is emitting elastic (AE) waves which are detected by sensors. After the detection of AE signals, as dynamic motions at the surface of a material, these signals are converted into the electric signal that is further amplified (in cement-based materials the signals are usually amplified from $60 \mathrm{~dB}$ to $100 \mathrm{~dB}$ in total to be detected) and filtered $[3,4]$.

Because it is not always possible to place the acoustic emission sensors directly on the measured objects (due to reasons such as extreme surface tem- perature of the specimen that would damage the sensor, possible inaccessibility of the monitored part in relation to its construction, or unstable surface fresh mixture), acoustic waveguides are used. Their great disadvantage is the loss of the resulting signal size on the interface and signal attenuation in the material [5].

The AE method is commonly used during mechanical loading of structures, however, it has been shown that this method may also be well-suited for the investigation of other processes such as setting, hardening, and curing taking place in cement-based composites. These early processes are important and significantly influence the future properties of the material. During hydration processes, various physical and chemical processes take place, during which the given composite acquires chemical stability and mechanical properties [6].

The setting process can be characterized as a state in which the slurry loses its workability and gradually acquires strength. This process is followed by the

This is an open-access article distributed under the terms of the Creative Commons Attribution-NonCommercial 4.0 International License (https://creativecommons.org/licenses/by-nc/4.0/), which permits unrestricted use, distribution, and reproduction in any medium for non-commercial purposes, provided the original author and source are credited, a link to the CC License is provided, and changes - if any - are indicated. 


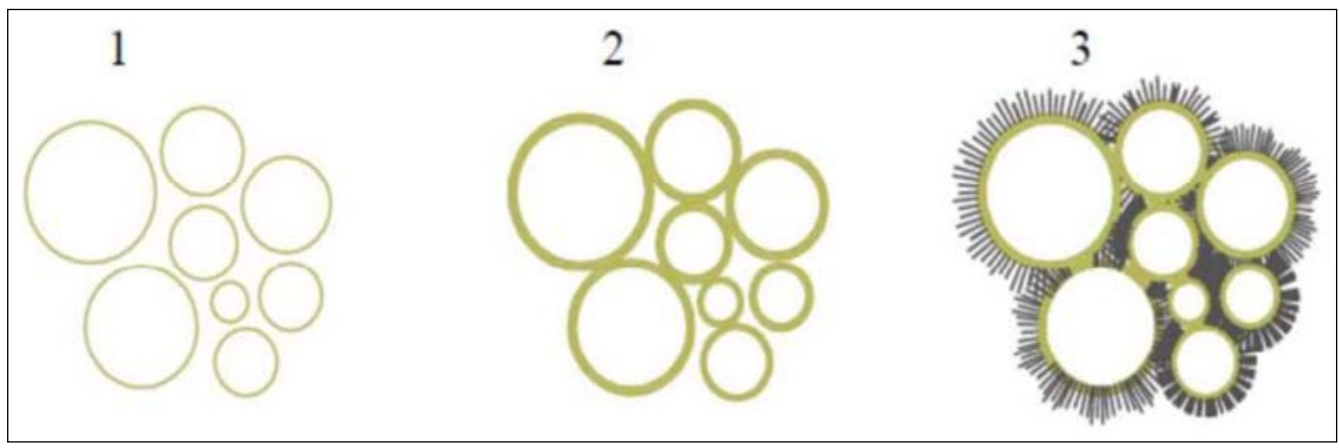

Fig. 1. Cross-section of cement grains to represent the hydration stages in Portland cement [7]. 1. Before contact with water, 2 . shortly after contact with water (C-S-H gel around the grains and long thin ettringite needles), 3. intertwining of the needles and continuation of hydration by joining all the components of the phases

hardening process, when the newly formed solid material gradually acquires higher strength [7].

Depending on the specific degree of the reaction of the Portland cement with water, it is possible to divide hydration of cement into five stages: I. mixing with water, II. induction period, III. start of setting, IV. hardening, V. hydration deceleration [8].

When mixing cement with water, ions are released into the initial solution. It is a chemical reaction with a massive release of the heat of reaction. The cement grains begin to be covered with the C-S-H gel formed from the silicate phases of clinker and ettringite.

The next stage, called the induction period, follows, in which the release of the heat slows down, the $\mathrm{pH}$ value increases rapidly and the concentration of $\mathrm{Ca}^{2+}$ ions in the mixing water decreases (together with the hydrates formed on the surface of the particles) the solubility of the Portland clinker phases. The beginning of setting of the cement paste can occur in case the system is saturated with calcium ions, when the system is unstable. The $\mathrm{Ca}^{2+}$ ions therefore reach the saturation degree and the formation of ettringite continues. The cause of the start and end of the induction period is the subject of many discussions [7-9].

During the beginning of setting, a gradual decrease of the concentration of $\mathrm{Ca}^{2+}$ and $\mathrm{OH}$ - ions in the solution occurs, all the Portland cement phases begin to dissolve and heat is released again. This hydration stage is also accelerated by the presence of C3S. $\mathrm{C}-\mathrm{S}-\mathrm{H}$ is formed, which leads to the increase of the strength of the given system because the grains get closer together and join. In addition to the formation of C-S-H, CH phases are also formed and fill the space between the cement grains. The formation of ettringite continues [8].

In the next stage (hardening), most cements do not contain a sufficient amount of calcium sulphate to react with all aluminate phases of the Portland clinker. After the formation of ettringite depletes the $\mathrm{SO}_{4}{ }^{2-}$ ions, ettringite becomes unstable and recrystallizes under the formation of monosulfate, and the hydration is slowed down in the last stage [7, 8].

\section{Composition of the composite}

Two fine-grained cement composites, high-strength mortar without microsilica (composite A) and high strength mortar with microsilica (composite B) were produced for the purpose of the experiment. The composite $\mathrm{A}$ is a transition from conventional mortars to mortars with ultra-high strengths (Reactive Powder Concrete) based on fine-grained components. The key difference from concrete is that the mortar contains only grains up to $4 \mathrm{~mm}$. This means that there should be far less intensive cracking of the shrinking hardening cement paste around large grains, as is the case in concrete.

Table 1. Components for $1 \mathrm{~m}^{3}$ of the mixture

\begin{tabular}{|c|c|c|}
\hline \multirow{2}{*}{ Component } & Composite A & Composite B \\
\hline & \multicolumn{2}{|c|}{ Weight $[\mathrm{kg}]$} \\
\hline CEM I $42.5 \mathrm{R}$ & 1000 & 740 \\
\hline Stach. 2280 & 15 & 15 \\
\hline Water & 280 & 260 \\
\hline Hulín 0/4 & 940 & 1245 \\
\hline Fibres $6 \mathrm{~mm}$ & 10.5 & 10.5 \\
\hline Microsilica & - & 60 \\
\hline
\end{tabular}

\section{Description of the experiment}

Two additional holders were attached to the steel form to fix the acoustic emission sensor-waveguides (Fig. 2). Acoustic emission measurements were performed using the DAKEL XEDO equipment. 


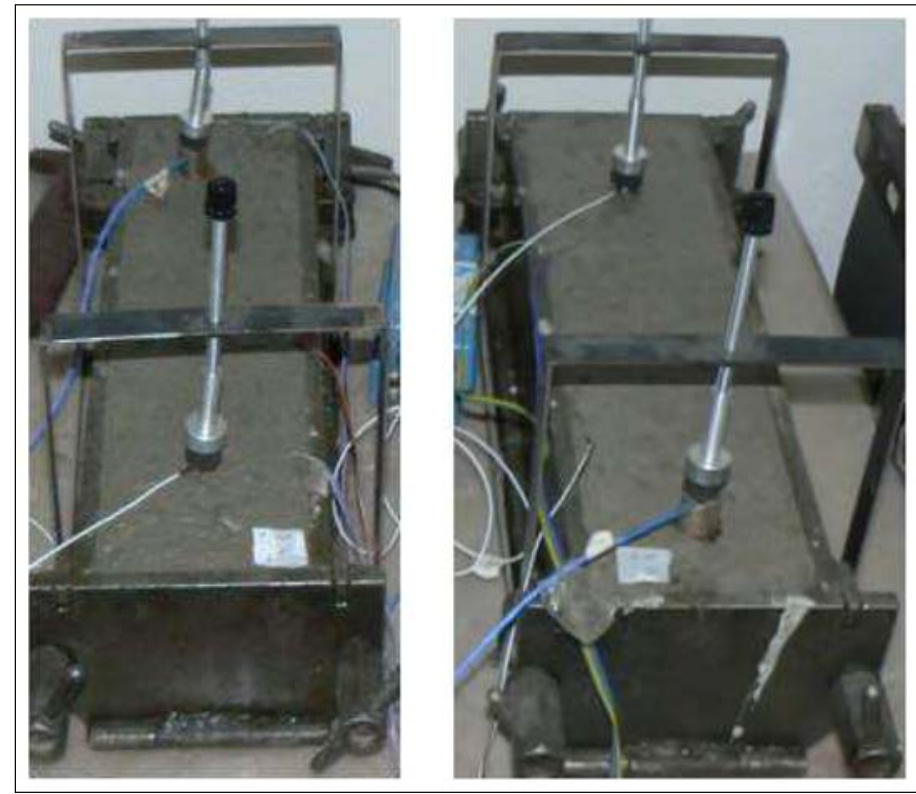

Fig. 2. Photographs from the production with the layout and details of distribution of the AE sensors (composite A (left), composite B (right))

\section{Results}

When monitoring the acoustic activity of the material during setting and the early phase of hardening, the composite A exhibited the largest increase in the number of acoustic emission events at the beginning of the measurement. This is approximately 8 hours after mixing the mixture. From 28 hours after the start of the measurement, the acoustic emission events are minimal. The composite B has two sharp increases in the number of the acoustic emission events, the first being from the beginning of the measurement to 3 hours and the second one between the 5th and 6th hour of the measurement.

A comparison of both samples shows that while the composite A has a slightly faster onset of the acoustic emission events, it is the mixture $B$ which has slightly more acoustic events overall in the 48-hour measurement period. However, both cases are probably within measurement errors.

The development of the internal temperature in the composite $\mathrm{A}$ in regard to the ambient temperature was initially rapid, a gradual decrease followed and stopped at the temperature of $30^{\circ} \mathrm{C}$. Subsequently, an-

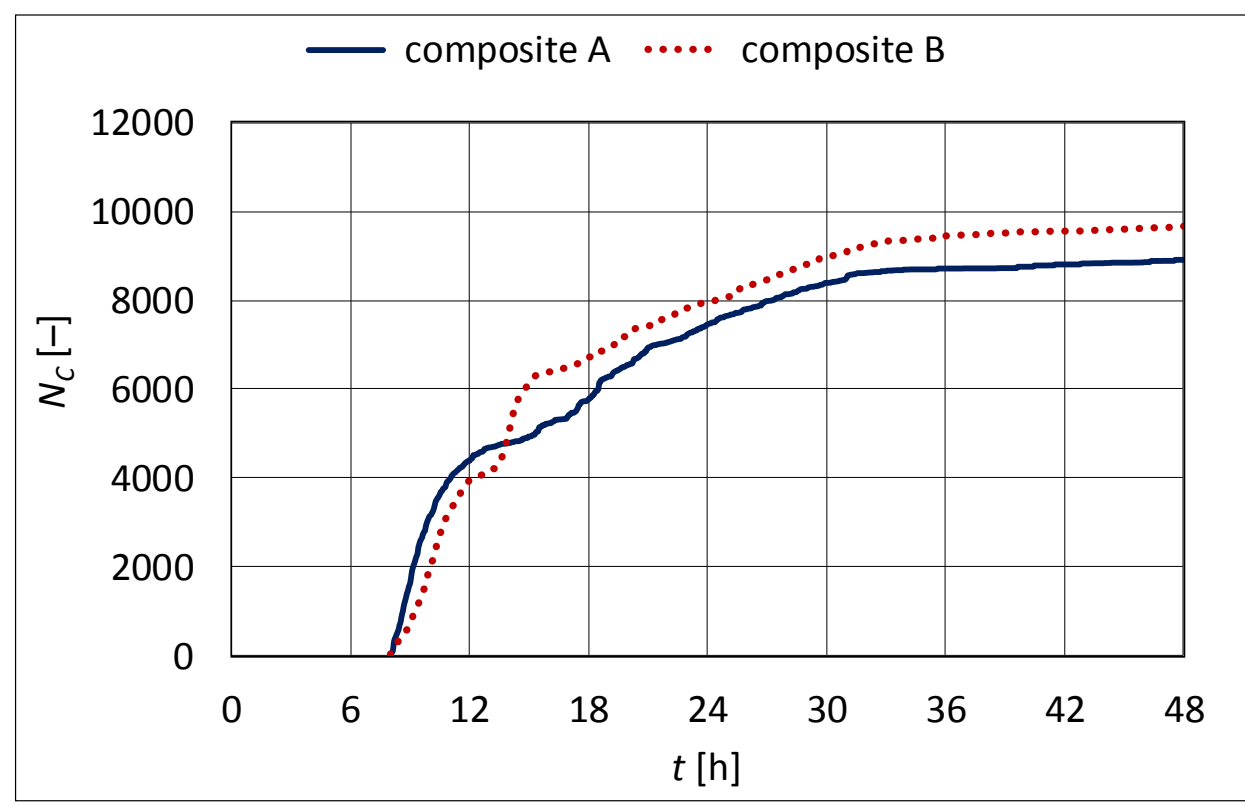

Fig. 3. Comparison of the total dependencies of cumulative frequency on time (composite A and composite B) 


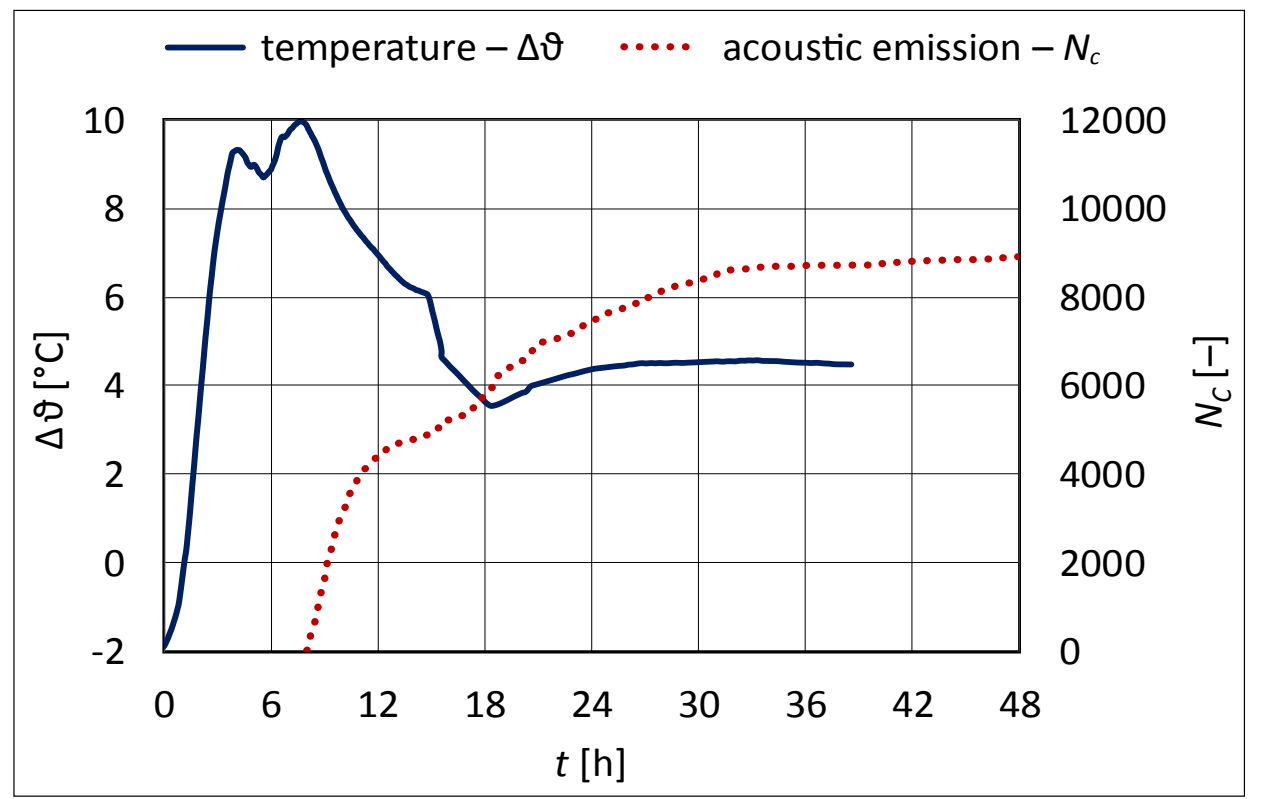

Fig. 4. The development of the number of events and difference between the internal temperature of the sample and the ambient temperature in regard to time (composite A)

other considerably slower increase began, which later stabilized (after 30 hours from the start of measurement) at $34{ }^{\circ} \mathrm{C}$, which was $4{ }^{\circ} \mathrm{C}$ above the ambient temperature.

The development of the internal temperature of the composite B was very gradual. After the first peak, a slight decrease occurred and stopped at the temperature of $36^{\circ} \mathrm{C}$, which was $8{ }^{\circ} \mathrm{C}$ above the ambient temperature.

The amplitude of the AE signal is a useful parameter because it indicates the size of the detectable acoustic emission event (the detection depends on the amplitude that exceeds the threshold value). The amplitude of the AE signal is usually given in decibels and the monitoring interval is usually between 0 and $100 \mathrm{~dB}$, then we can distinguish for example events with amplitudes:

$$
\begin{aligned}
<35 \mathrm{~dB} & - \text { small } \\
35-55 \mathrm{~dB} & - \text { medium } \\
55-75 \mathrm{~dB} & - \text { large } \\
>75 \mathrm{~dB} & - \text { very large }
\end{aligned}
$$

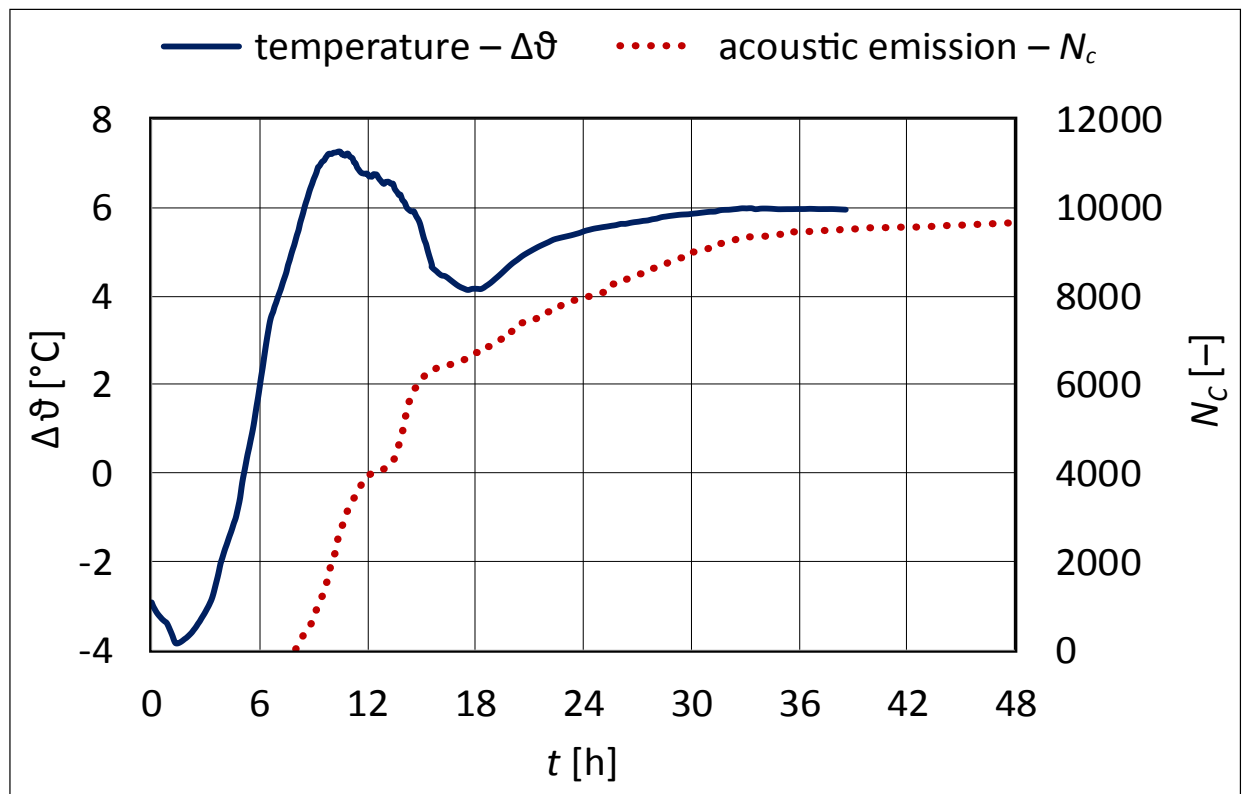

Fig. 5. The development of the number of events and difference between the internal temperature of the sample and the ambient temperature in regard to time (composite B) 


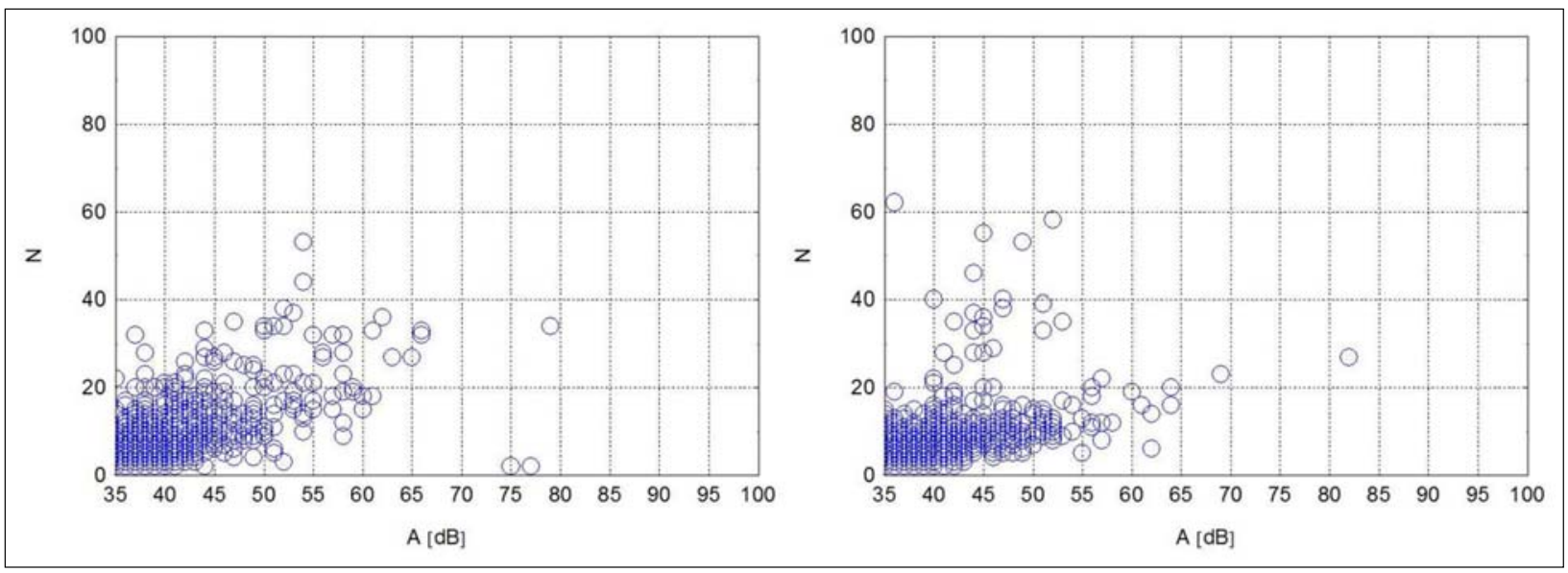

Fig. 6. Comparison of the dependence of the number of events on the amplitude (composite A - left, composite B - right)

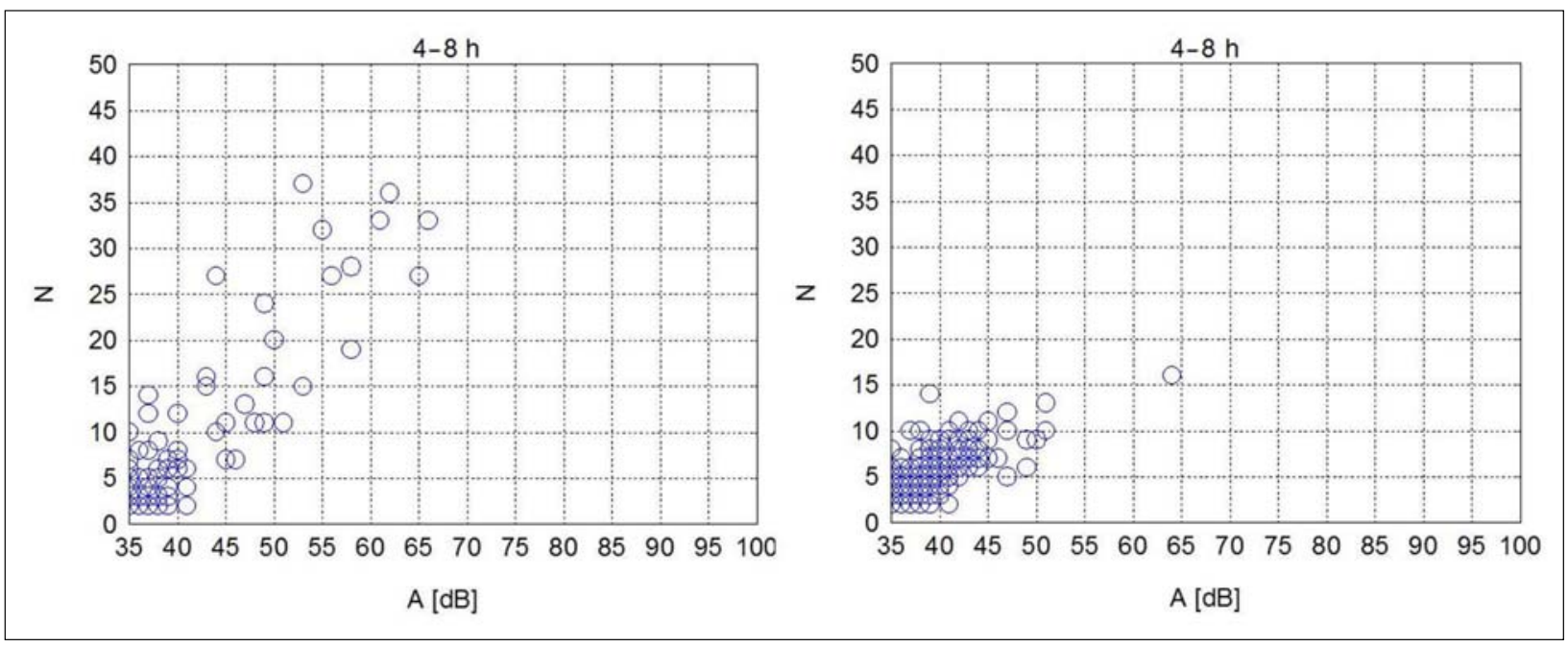

Fig. 7. Comparison of the dependence of the number of events on the amplitude (interval 4-8 hours), (composite A - left, composite B - right)

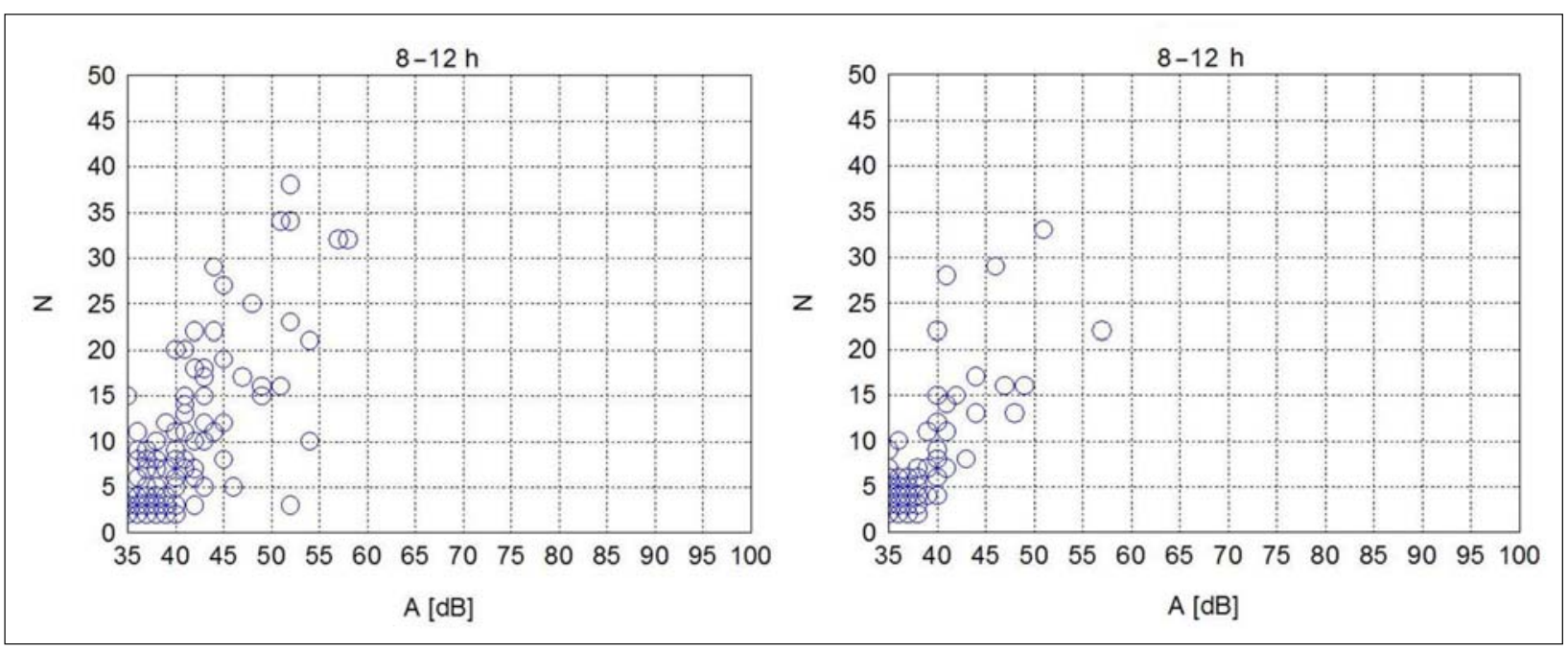

Fig. 8. Comparison of the dependence of the number of events on the amplitude (interval 8-12 hours), (composite A - left, composite B - right) 
The composite A exhibits an even distribution of the dependence of the number of events on the amplitude. Medium amplitudes are predominant with an almost negligible amount of very large amplitudes. The composite B predominantly exhibits medium amplitudes and that only in small numbers. Large amplitudes are also present, but only in negligible amounts.

The following graphs show that in the first part from the beginning of the measurement and therefore also setting, the composite A exhibits more events with higher amplitude. It can therefore be assumed that larger microcracks are being formed in it.

The greater amount of the cement paste in the mortar without microsilica can be responsible for the higher number of higher amplitudes: $1000 \mathrm{~kg}$ of cement $+280 \mathrm{~kg}$ of water $\approx 6031$, while in the other case it is: $740 \mathrm{~kg}+60 \mathrm{~kg}$ microsilica $+260 \mathrm{~kg}$ water $\approx 5261$.

\section{Conclusion}

The described acoustic emission method is one of the non-destructive test methods that, unlike most other methods, only capture active events in the structure of the material or construction. The evaluation of the experiment indicated that the acoustic emission method belongs among prospective methods that can be used both in the laboratory and in practical situations for long term monitoring of the condition of constructions, as a suitable supplement to commonly used methods.

The conducted experiments indicate that the higher amplitude values of the acoustic emission signals correspond to more significant structural changes that occur in the material, whether they be new products or the formation or growth of microcracks. It can also be stated that the addition of microsilica does not have a significant influence on the amount of the AE events when compared to composites without microsilica.

\section{Acknowledgements}

This research was supported by the project No. FAST-J-18-5369 "Využití metody akustické emise pro experimentální určení vývoje poškození jemnozrnných kompozitů během zatěžování”, supported by Brno University of Technology.

\section{References}

[1] Mazal P., Pazdera L., Nohál L., Topoláŕ L. (2012), Netradiční aplikace metody akustické emise. Brno: VUT v Brně, 102 s. ISBN: 978-80-214-4629-8.

[2] Dzaye E. D., De Schutter G., Aggelis D., Dimitrios G. (2018), Study on mechanical acoustic emission sources in fresh concrete. Archives of Civil and Mechanical Engineering, 18(3), 742-754.

[3] Grosse CU, Ohtsu M. (ed.) (2008), Acoustic Emission Testing. Springer Science \& Business Media.

[4] Dzaye E. D., De Schutter G., Aggelis D. (2017), Early-age monitoring of fresh cementitious material by acoustic emission. In: Staquet S, Aggelis D, eds. Early Age Cracking and Serviceability in Cement-based Materials and Structures. Paris (France): RILEM Publications, pp. 417422.

[5] Černý M., Mazal P., Filípek J. (2008), Sensing of the acoustic signal by waveguides. Acta Univ. Agric. et Silvic. Mendel. Brun., LVI(1), 43-54.

[6] Topoláŕ L. (2008), Využití akustických metod k popisu chování betonových stavebních struktur při jejich tuhnutí a zatěžování. Brno. Disertační práce. Vysoké učení technické v Brně. Vedoucí práce Doc. Ing. Luboš Pazdera, CSc.

[7] Tichá P. (2012), Rané stádium tuhnutí cementové pasty. Praha, Disertační práce. České Vysoké Učení Technické v Praze. Vedoucí práce Prof. RNDr. Pavel Demo, CSc.

[8] Tichá P., Demo P., Sveshnikov A., Semerák P. (2006), Early Stage of Cement Paste Hydration. In: Proceedings of International Workshop: Physical and Material Engineering. Bratislava: Slovak University of Technology, pp. 240-243. ISBN 80-227-2467-X.

[9] Singh L. P., Bhattacharyya S. K., Shah S. P., Mishra G., Ahalawat S., Sharma U. (2015), Studies on early stage hydration of tricalcium silicate incorporating silica nanoparticles: Part I. Construction and Building Materials, 74, 278-286. 